\title{
Broad-Spectrum Protection Against Several Pathogens by PGPR Mixtures Under Field Conditions in Thailand
}

\author{
Kanchalee Jetiyanon, Department of Agricultural Sciences, Faculty of Agriculture, Natural Resources, and Envi- \\ ronmental Sciences, Naresuan University, Phitsanulok, Thailand 65000; William D. Fowler and Joseph W. Kloepper, \\ Department of Entomology and Plant Pathology, College of Agriculture, Auburn University, Auburn, AL 36849
}

\begin{abstract}
Jetiyanon, K., Fowler, W. D., and Kloepper, J. W. 2003. Broad-spectrum protection against several pathogens by PGPR mixtures under field conditions in Thailand. Plant Dis. 87:13901394.

Prior greenhouse experiments showed that four mixtures of plant growth-promoting rhizobacteria (PGPR) strains (all Bacillus spp.) elicited induced systemic resistance in several plants against different plant pathogens. Based on these findings, we sought to determine if systemic resistance induced by these PGPR would lead to broad-spectrum protection against several pathogens under field conditions in Thailand. Experiments were conducted during the rainy season (July to October 2001) and winter season (November 2001 to February 2002) on the campus of Naresuan University, Phitsanulok, Thailand. The specific diseases and hosts tested were southern blight of tomato (Lycopersicon esculentum) caused by Sclerotium rolfsii, anthracnose of long cayenne pepper (Capsicum annuum var. acuminatum) caused by Colletotrichum gloeosporioides, and mosaic disease of cucumber (Cucumis sativus) caused by Cucumber mosaic virus (CMV). Results showed that some PGPR mixtures suppressed disease more consistently than the individual PGPR strain IN937a. One PGPR mixture, Bacillus amyloliquefaciens strain IN937a $+B$. pumilus strain IN937b, significantly protected $(P=0.05)$ plants against all tested diseases in both seasons. Further, cumulative marketable yields were positively correlated with some treatments.
\end{abstract}

Additional keywords: biological control, plant growth promotion, systemic protection

Vegetable crops represent an important export commodity for Thailand. In 2001, Thailand's exports of edible vegetables and certain roots and tubers were valued at US\$32 million. Among the most commonly grown vegetables are tomato ( $L y$ copersicon esculentum Mill.), long cayenne pepper (Capsicum annuum L. var. acuminatum Fingerh), and cucumber ( $\mathrm{Cu}$ cumis sativus L.). Unfortunately, diseases of vegetables are often more prevalent and severe in the subtropics and the tropics, including Thailand, due to climates being conducive to disease dissemination and development $(3,10,11,30)$.

Vegetable production in Thailand usually involves maximum inputs of various pesticides. Thai growers spend approximately $15 \%$ of total costs for chemicals to control plant diseases (23). At the same time, there is growing interest in Thailand in producing high-quality vegetables that have little or no pesticide residue. These factors have prompted the consideration of biological disease control strategies (9). In

Corresponding author: J. W. Kloepper

E-mail: jkloeppe@acesag.auburn.edu

Accepted for publication 26 June 2003.

Publication no. D-2003-0908-03R

(C) 2003 The American Phytopathological Society
Thailand, the main mechanism for achieving biological control in fruit and vegetable crops has been antagonism, especially the use of fungal biocontrol agents $(6,7,12,13,29)$. Induced systemic resistance (ISR) elicited by plant growth-promoting rhizobacteria (PGPR) has not yet been reported for biological control of diseases in Thai vegetable field crops but has attracted interest from scientists because it has led to disease reduction and promotion of plant growth and yield $(22,33)$. Several greenhouse and field studies have demonstrated that treating cucumber seeds with either a single PGPR strain or a mixture of strains results in ISR activity against several pathogens $(20,21,26-28,33)$. We previously reported (15) that compatible PGPR mixtures can elicit ISR in various plants including: cucumber (cv. Thong) against mosaic disease caused by Cucumber mosaic virus (CMV); green kuang futsoi (Brassica chinensis Jusl var. parachinensis (Bailey) Tsen \& Lee cv. 610 Show-Jean) against damping-off disease caused by Rhizoctonia solani Kühn; long cayenne pepper (cv. 111 CHANYA) against anthracnose disease caused by Colletotrichum gloeosporioides (Penz.) Penz. \& Sacc.; and tomato (cv. Srida) against wilt disease caused by Ralstonia solanacearum (Smith) Yabuuchi et al. (15).

Growers in Thailand generally use multi- or inter-cropping systems for grow- ing vegetables. Several different diseases often occur in different crops in the same field during a single growing season. Thus, the objective of this study was to evaluate the effectiveness of compatible PGPR mixtures that elicit ISR against multiple diseases in different hosts during the rainy and winter seasons in Thailand. We studied three major diseases that occur on vegetable crops in Thailand: anthracnose disease caused by $C$. gloeosporioides on long cayenne pepper, southern blight disease caused by Sclerotium rolfsii on tomato, and mosaic disease caused by CMV on cucumber.

\section{MATERIALS AND METHODS}

Bacterial cultures. The PGPR used in this study were Bacillus amyloliquefaciens strain IN937a and Bacillus pumilus strains IN937b, SE34, SE49, T4, and INR7. All strains were obtained from the culture collection of the phytobacteriology laboratory of Auburn University. In previous greenhouse tests, individual PGPR strain IN937a and compatible PGPR mixtures $($ IN937a + IN937b, IN937b + SE34, IN937b + SE49, and T4 + INR7) induced systemic protection in various plants (15).

The bacteria were maintained in tryptic soy broth (TSB) (Difco Laboratories, Detroit, MI) supplemented with $20 \%$ glycerol at $-80^{\circ} \mathrm{C}$ for long-term storage. For experimental use, bacteria were transferred into TSB for $24 \mathrm{~h}$. The concentration was then adjusted in sterile distilled water to $10^{11} \mathrm{CFU} / \mathrm{ml}$ for seed treatment or $10^{8}$ $\mathrm{CFU} / \mathrm{ml}$ for root treatment.

Pathogens, hosts, media, and culture conditions. A culture of C. gloeosporioides was provided by the Plant $\mathrm{Pa}$ thology and Microbiology Division, Department of Agriculture, Ministry of Agriculture and Cooperatives, Thailand. Conidial suspensions of C. gloeosporioides were maintained in cryovials containing TSB supplemented with $20 \%$ glycerol and kept at $-80^{\circ} \mathrm{C}$ for long-term storage. For experimental use, conidia were transferred to plates of potato dextrose agar (PDA; Difco) and incubated at $30^{\circ} \mathrm{C}$ for 7 days. Dried leaf tissue of tobacco (Nicotiana tabacum L. cv. White Burley) infected with CMV was provided by Orawan Chatchawankanphanich of Kasetsart University, Nakorn Pathom, Thailand, who identified the pathogen by both enzymelinked immunosorbent assay (ELISA) and reverse transcriptase technique. One gram 
of leaf tissue was ground in a mortar with $10 \mathrm{ml}$ of $0.01 \mathrm{M}$ sodium phosphate buffer (SPB; $\mathrm{pH}$ 7.0). The supernatant containing CMV inoculum was swabbed onto the cotyledons of 10-day-old cucumber (cv. Thong) using sterile cotton. When symptomatic leaves appeared on inoculated cucumber plants, the young infected leaves were harvested and maintained at $-80^{\circ} \mathrm{C}$ for further experimental use.

Field experiments. Field experiments were conducted to determine whether selected PGPR treatments could elicit ISR activity against target pathogens. Field trials were conducted in the rainy season (July to October 2001) and the winter season (November 2001 to February 2002) at the Field Research Experimental Unit of the Faculty of Agriculture, Natural Resources, and Environmental Sciences, Naresuan University, Phitsanulok, Thailand. During each season, there were three experiments (one each for cucumber, tomato, and long cayenne pepper). The experimental design was a randomized complete block (RCB) with six treatments and three replications. Plots were $1 \mathrm{~m}$ wide by $3 \mathrm{~m}$ long. Each plot was separated by $1 \mathrm{~m}$, and six plants within were spaced at $50 \mathrm{~cm}$. Plots were covered with white polyethylene plastic film. Weeds were periodically eradicated either mechanically or by hand. Treatments consisted of a nonbacterized control, individual PGPR strain IN937a, and four mixtures of PGPR (IN937a + IN937b, IN937b + SE34, IN937b + SE49, and T4 + INR7).

Seeds of cucumber, tomato, and long cayenne pepper were soaked in bacterial suspensions $\left(10^{11}\right.$ cells per $\left.\mathrm{ml}\right)$ maintained

Table 1. Protection by plant growth-promoting rhizobacteria (PGPR) against Cucumber mosaic virus on cucumber in field trials ${ }^{\vee}$

\begin{tabular}{lcc}
\hline Treatment $^{w}$ & $\begin{array}{c}\text { Mean }^{\mathbf{x}} \\
(\text { rainy) }\end{array}$ & $\begin{array}{c}\text { Mean }^{\mathbf{y}} \\
\text { (winter) }\end{array}$ \\
\hline Control & $6.0 \mathrm{a}^{\mathrm{z}}$ & $6.0 \mathrm{a}$ \\
IN937a alone & $2.3 \mathrm{~b}$ & $3.0 \mathrm{~b}$ \\
IN937a+IN937b & $2.3 \mathrm{~b}$ & $3.3 \mathrm{~b}$ \\
IN937b+SE34 & $1.3 \mathrm{~b}$ & $3.3 \mathrm{~b}$ \\
IN937b+SE49 & $1.3 \mathrm{~b}$ & $3.0 \mathrm{~b}$ \\
T4+INR7 & $2.3 \mathrm{~b}$ & $2.7 \mathrm{~b}$ \\
LSD $_{0.01}$ & 2.8 & 1.1 \\
\hline
\end{tabular}

${ }^{\mathrm{v}}$ Field experiments were conducted in the rainy season (July-October 2001) and winter season (November 2001-February 2002). The experimental design was a randomized complete block of six treatments with three replications, each with six plants.

${ }^{\text {w }}$ PGPR strain identifications: Strain IN937a = Bacillus amyloliquefaciens; Strains IN937b, SE34, SE49, T4, and INR7 = B. pumilus .

${ }^{x}$ Mean of mosaic disease incidence (number of plants showing symptoms) on cucumber plants was obtained 22 days after challenge.

y Mean of mosaic disease incidence on cucumber plants was obtained 28 days after challenge.

${ }^{\mathrm{z}}$ Numbers with different letters show significant differences at $P=0.01$ according to the least significant difference (LSD) test. in 100-ml flasks and were then incubated in an orbital incubator shaker (100 rpm, Gyromax 707, Amerex Instrument, Lafayette, CA) at $30^{\circ} \mathrm{C}$ for $60 \mathrm{~min}$. They were planted in a plastic seedling tray containing sterile soilless peat (Florafleur, NEVEMA B. V., Zwolle, Holland). The nonbacterized control treatment was soaked in TSB. All plants were grown in the greenhouse. Each cucumber plant was transferred into a plastic pot (10 cm diameter) 4 days after seeding. Tomato and pepper plants were transferred into plastic pots 7 days after seeding. At 5 days after planting, each cucumber pot was drenched with $50 \mathrm{ml}$ of bacterial suspension $\left(10^{8}\right.$ cells per $\left.\mathrm{ml}\right)$. At 1 month after planting, each pot of tomato and pepper was drenched with the same amount and the same bacterial concentration. Control pots were drenched with 50 $\mathrm{ml}$ of diluted TSB in sterile distilled water $(1.0 \mathrm{ml}$ of TSB in 1.0 liter of sterile distilled water). Plants were transferred to the field site 9 days after soil drench. Liquid fertilizer (15-15-15) was sprayed onto plant leaves until runoff 1 day before transplanting to the field.

Cucumber mosaic disease. Cucumber plants were artificially challenged with CMV by rub-inoculation with infected sap at the first true leaves 7 days after transplanting. Inoculated leaves were immediately rinsed with water to remove the sap extract. The length of the main runner of each plant was recorded 1 month after transplanting. Mosaic symptoms were observed daily until 22 days after challenge in rainy season and 28 days after challenge in winter season. Disease incidence was calculated by the percentage of plants showing mosaic symptoms on younger leaves. Liquid fertilizer was applied again when plants began flower set. Marketable cucumber fruits $(3.5$ to $4 \mathrm{~cm}$ in diameter, 10 to $14 \mathrm{~cm}$ in length) were harvested every 3 days until the end of the season, and the fruit weight from each treatment was totaled for statistical analysis.

Table 2. Effect of plant growth-promoting rhizobacteria (PGPR) on cucumber fruit fresh weight and runner length in field trials ${ }^{\mathrm{v}}$

\begin{tabular}{lccccc}
\hline & \multicolumn{2}{c}{ Mean total fruit weight $\mathbf{( k g / p l o t )})^{\mathbf{x}}$} & & \multicolumn{2}{c}{ Mean main runner length $(\mathbf{c m})^{\mathbf{y}}$} \\
\cline { 2 - 3 } \cline { 5 - 6 } Treatment $^{\mathbf{w}}$ & Rainy season & Winter season & & Rainy season & Winter season \\
\hline Control & $3.3 \mathrm{~b}^{\mathrm{z}}$ & $5.5 \mathrm{~b}$ & & $104.3 \mathrm{de}$ & $111.7 \mathrm{~b}$ \\
IN937a alone & $4.5 \mathrm{ab}$ & $8.4 \mathrm{ab}$ & & $119.8 \mathrm{bc}$ & $137.8 \mathrm{a}$ \\
IN937a+IN937b & $5.0 \mathrm{a}$ & $6.0 \mathrm{ab}$ & & $129.1 \mathrm{ab}$ & $139.3 \mathrm{a}$ \\
IN937b+SE34 & $3.7 \mathrm{ab}$ & $7.5 \mathrm{ab}$ & & $114.4 \mathrm{~cd}$ & $116.3 \mathrm{~b}$ \\
IN937b+SE49 & $3.5 \mathrm{ab}$ & $7.9 \mathrm{ab}$ & & $99.7 \mathrm{e}$ & $129.2 \mathrm{ab}$ \\
T4+INR7 & $4.7 \mathrm{ab}$ & $9.4 \mathrm{a}$ & & $135.3 \mathrm{a}$ & $142.6 \mathrm{a}$ \\
LSD $_{0.05}$ & $1.5 \mathrm{ab}$ & 3.6 & & 13.0 & 18.2 \\
\hline
\end{tabular}

${ }^{v}$ Field experiments were conducted in the rainy season (July-October 2001) and winter season (November 2001-February 2002). The experimental design was a randomized complete block of six treatments with three replications, each with six plants.

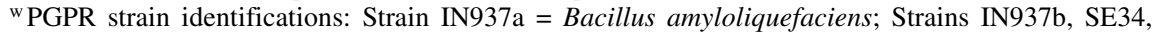
SE49, T4, and INR7 = B. pumilus.

${ }^{x}$ Mean total fruit weight from six plants per plot from cumulative harvests until the end of the season.

${ }^{y}$ Mean length of main runner was measured 1 month after transplanting.

${ }^{\mathrm{z}}$ Numbers with different letters show significant differences at $P=0.05$ according to least significant difference (LSD) test.
Tomato southern blight disease. Liq-
uid fertilizer was applied again when plants began flower set. Inoculum of the present in the tomato field site. The planting. All plants were rated for disease leaves (yellowing and wilting leaves) per calculated as the percentage of sympto per plant. Tomato fruits with marketvested three times from each treatment, and totaled for statistical analysis.

Pepper anthracnose disease. Liquid began flower set. Approximately 55 days soil drench, pepper fruits were chalsporioides $\left(10^{5}\right.$ spores per $\left.\mathrm{ml}\right)$ suppleSwitzerland). The suspensions were sprayed onto pepper fruits in the evening challenge, fully developed pepper fruits were collected from each plant and rated calculated as the percentage of fruit area with symptoms. yzed by analysis of variance (ANOVA). ercent values for disease incidence on and long cayenne pepper were transformed Least significant difference (LSD) tests performed to compare treatment were performed with the GLM procedure of SAS version 8, 1990 (SAS Institute, Cary, NC).

RESULTS

Cucumber mosaic disease. In the rainy season, all plants in the nonbacterized consouthern blight pathogen, $S$. rolfsii, was 
trol showed mosaic symptoms 13 days after challenge, especially in the younger leaves. In contrast, symptoms were noted on only some plants in the bacterized treatments (data not shown). Even though more plants in the bacterized treatments exhibited disease symptoms at 22 days after challenge than at 13 days, the disease incidence in all bacterized treatments was significantly lower than in the control (Table 1). Some infected plants in the control had severe systemic disease and were stunted. PGPR strain mixtures IN937b + SE34 and IN937b + SE49 provided approximately $80 \%$ disease suppression, and the remaining PGPR treatments provided approximately $60 \%$ disease suppression compared with the control. In the middle of the season, cucurbit leaf beetles (Aulacophora similis Oliver) infested cucumber plants and increased in population quickly throughout the season. These beetles severely damaged cucumber leaves, stems, and flowers. Total cucumber fruit weight in most PGPR treatments was greater than that for the control (Table 2). However, only mixture IN937a + IN937b produced significantly higher yield $(P=0.05)$.

In the winter season field trial, the appearance of mosaic symptoms on cucumber plants was delayed both in nonbacterized and PGPR treatments. All plants in the control showed mosaic symptoms on young leaves 28 days after challenge. Even though the level of disease suppression (45 to $55 \%$ ) in PGPR treatments was lower than in the rainy season, disease incidence in all PGPR treatments was significantly less than in the control (Table 1). The damage caused by the beetles was negligible in

Table 3. Protection by plant growth-promoting rhizobacteria (PGPR) of tomato against southern wilt disease caused by Sclerotium rolfsii in field trials ${ }^{\mathrm{w}}$

\begin{tabular}{llc}
\hline Treatment $^{\mathbf{x}}$ & $\begin{array}{c}\text { Mean } \\
\text { (rainy) }\end{array}$ & $\begin{array}{c}\text { Mean }^{\mathbf{y}}(\%) \\
\text { (winter) }\end{array}$ \\
\hline Control & $70.8 \mathrm{a}^{\mathrm{z}}$ & $72.7 \mathrm{a}$ \\
IN937a alone & $16.7 \mathrm{~b}$ & $48.1 \mathrm{ab}$ \\
IN937a+IN937b & $23.9 \mathrm{~b}$ & $38.7 \mathrm{~b}$ \\
IN937b+SE34 & $58.0 \mathrm{ab}$ & $46.9 \mathrm{~b}$ \\
IN937b+SE49 & $34.7 \mathrm{ab}$ & $53.6 \mathrm{ab}$ \\
T4+INR7 & $57.5 \mathrm{ab}$ & $41.4 \mathrm{~b}$ \\
LSD $_{0.05}$ & 44.4 & 25.2 \\
\hline
\end{tabular}

${ }^{\text {w}}$ Field experiments were conducted in the rainy season (July-October 2001) and winter season (November 2001-February 2002). The experimental design was a randomized complete block of six treatments with three replications, each with six plants.

$\times$ PGPR strain identifications: Strain IN937a $=$ Bacillus amyloliquefaciens; Strains IN937b, SE34, SE49, T4, and INR7 = B. pumilus.

${ }^{y}$ Mean disease severity. Disease was rated 2 months after transplanting by determining percentage of symptomatic leaves (yellowing and wilting) per plant.

${ }^{\mathrm{z}}$ Numbers with different letters show significant differences at $P=0.05$ according to least significant difference (LSD) test. this season. Only PGPR mixture T4 + INR7 gave significantly $(P=0.05)$ higher yields than plants in the control (Table 2 ).

For plant growth promotion, individual PGPR strain IN937a and two PGPR strain mixtures, IN937a + IN937b and T4 + INR7, significantly enhanced the length of the main runner compared with the nonbacterized control in both the rainy and winter season trials (Table 2). Further, PGPR strain mixtures (IN937a + IN937b and T4 + INR7) resulted in greater growth promotion than did individual strain IN937a (Table 2).

Southern blight disease of tomato. In the rainy season, when symptoms occurred, they were first apparent on lower leaves 1 month after transplanting. The leaves began to turn yellow, wilt, or die from the tips downward in the nonbacterized control and in some plants of the bacterized treatments. S. rolfsii grew upward in the plant and covered the tomato stem with a cotton-like, white mass of mycelium. Invaded stem tissues were pale brown. The fungus produced numerous small sclerotia of uniform size that were white when immature and then became dark brown to black when they matured. IN937a alone and the mixture IN937a + IN937b showed significant $(P=0.05)$ reductions in disease severity of 75 and $65 \%$, respectively, compared with the control (Table 3). Mixture IN937a + IN937b resulted in a significant $(P=$ 0.05 ) yield increase of total marketable fruit that was 1.5 times that of the control treatment (Table 4).

In the winter season, the lower leaves on most tomato plants began to turn yellow, wilt, or die from the tips downward at 1 month after transplanting. Disease development progressed more quickly and with greater severity than in the rainy season. Two months after transplanting, the mixtures IN937a + IN937b, T4 + INR7, and IN937b + SE34 provided significant $(P=$ $0.05)$ disease suppression of 47,43 , and

Table 4. Effect of plant growth-promoting rhizobacteria (PGPR) on tomato growth and yield in field trials $^{\mathrm{v}}$

\begin{tabular}{lccccc}
\hline & \multicolumn{2}{c}{ Mean total fruit weight $(\mathbf{k g} / \mathbf{p l o t})^{\mathbf{x}}$} & & \multicolumn{2}{c}{ Mean plant height $(\mathbf{c m})^{\mathbf{y}}$} \\
\cline { 2 - 3 } \cline { 5 - 6 } Treatment $^{\mathbf{w}}$ & Rainy season & Winter season & & Rainy season & Winter season \\
\hline Control & $1.4 \mathrm{~b}^{\mathrm{z}}$ & $2.5 \mathrm{a}$ & & $97.1 \mathrm{c}$ & $83.8 \mathrm{bc}$ \\
IN937a alone & $2.0 \mathrm{ab}$ & $2.9 \mathrm{a}$ & & $111.5 \mathrm{a}$ & $74.4 \mathrm{c}$ \\
IN937a+IN937b & $2.4 \mathrm{a}$ & $3.7 \mathrm{a}$ & & $112.0 \mathrm{a}$ & $87.8 \mathrm{ab}$ \\
IN937b+SE34 & $1.6 \mathrm{ab}$ & $3.4 \mathrm{a}$ & & $101.4 \mathrm{abc}$ & $79.0 \mathrm{bc}$ \\
IN937b+SE49 & $1.7 \mathrm{ab}$ & $2.8 \mathrm{a}$ & & $109.3 \mathrm{ab}$ & $97.6 \mathrm{a}$ \\
T4+INR7 & $1.6 \mathrm{ab}$ & $3.4 \mathrm{a}$ & & $98.9 \mathrm{bc}$ & $100.6 \mathrm{a}$ \\
LSD $_{0.05}$ & 0.8 & 1.9 & & 11.7 & 13.1 \\
\hline
\end{tabular}

${ }^{\mathrm{v}}$ Field experiments were conducted in the rainy season (July-October 2001) and winter season (November 2001-February 2002). The experimental design was a randomized complete block of six treatments with three replications, each with six plants.

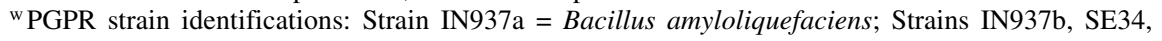
SE49, T4, and INR7 = B. pumilus.

${ }^{x}$ Mean total fruit weight from six plants per plot from two or three harvests for rainy and winter seasons.

${ }^{y}$ Mean height was obtained 1 month after transplanting.

${ }^{\mathrm{z}}$ Numbers with different letters show significant differences at $P=0.05$ according to least significant difference (LSD) test. 
resulted in significant $(P=0.05)$ yield increases in the winter (Table 6).

In the rainy season, broad mites (Polyphagotarsonemus latus Banks) infested some pepper plants and caused damage on the top parts of the plants. Red thrips (Scirtothrips dorsalis Hoods) were also found in this season. They caused the edges of lower leaves to curl downward and the upper plant to develop a reddish-brown color. A few leaf-eating caterpillars (Spodoptera litura (Fabr.)) and cotton bollworms were seen in some plants in both seasons, especially among fully developed pepper fruits. These insect pests did not cause significant damage, as the infested plant parts were immediately trimmed and destroyed by burning.

\section{DISCUSSION}

Our results demonstrate that PGPR strain IN937a and mixtures can elicit systemic protection against multiple diseases in different hosts under two field conditions, rainy and winter seasons, in Thailand. The systemic protection was associated with increased plant growth in most cases and sometimes with enhanced total yield. However, treatments that best reduced disease incidence or severity were not always the same as those that best enhanced plant growth or yield. Some tested PGPR strain mixtures more consistently suppressed either disease severity or disease incidence in both seasons than the individual PGPR strain IN937a. Mixture IN937a + IN937b elicited systemic protec-
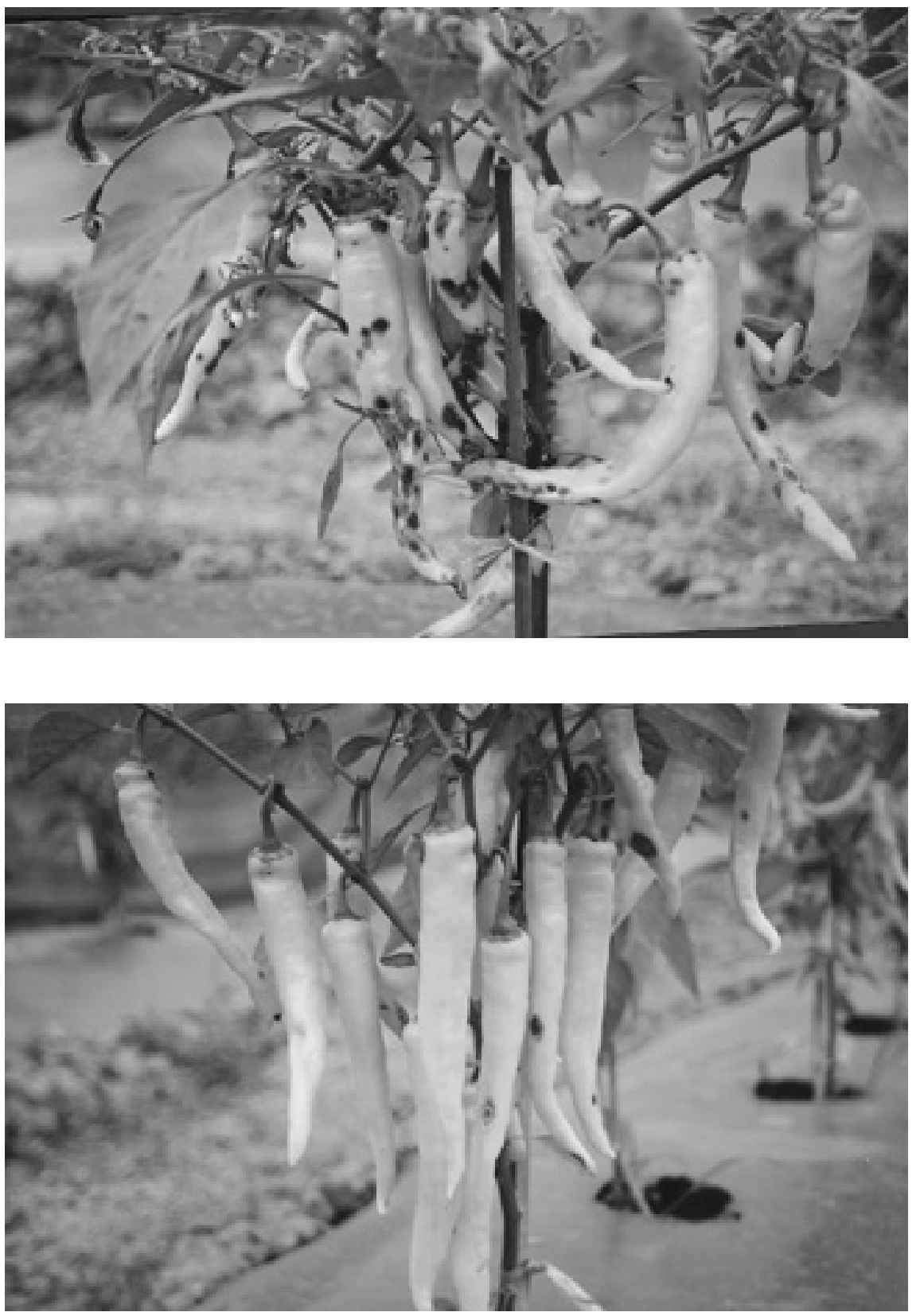

Fig. 1. Anthracnose symptoms on pepper fruits grown 3 months under field conditions during the winter season. Top $=$ nonbacterized control. Bottom $=$ treatment with plant growth-promoting rhizobacteria (PGPR) strain mixture IN937a + IN937b.

tion activity against all diseases (mosaic disease, wilt disease, and anthracnose disease) in both seasons. The individual strain IN937a elicited disease suppression against all diseases only in the rainy season for unknown reasons. PGPR strain mixtures IN937b + SE49 and T4 + INR7 suppressed mosaic and anthracnose diseases in both seasons. All PGPR treatments significantly reduced mosaic disease in both seasons when compared with the nonbacterized control.

Several host defenses have been reported to be involved with ISR elicited by

Table 5. Protection by plant growth-promoting rhizobacteria (PGPR) of long cayenne pepper against anthracnose disease caused by Colletotrichum gloeosporioides in field trials ${ }^{\mathrm{w}}$

\begin{tabular}{lcc}
\hline Treatment $^{\mathrm{x}}$ & $\begin{array}{c}\text { Mean } \\
\text { (rainy) }\end{array}$ & $\begin{array}{c}\text { Mean }(\%) \\
\text { (winter) }\end{array}$ \\
\hline Control & $51.4 \mathrm{a}^{\mathrm{z}}$ & $39.5 \mathrm{a}$ \\
IN937a alone & $20.0 \mathrm{~b}$ & $33.0 \mathrm{ab}$ \\
IN937a+IN937b & $16.5 \mathrm{~b}$ & $18.4 \mathrm{c}$ \\
IN937b+SE34 & $20.1 \mathrm{~b}$ & $34.1 \mathrm{ab}$ \\
IN937b+SE49 & $18.0 \mathrm{~b}$ & $28.3 \mathrm{~b}$ \\
T4+INR7 & $22.9 \mathrm{~b}$ & $16.5 \mathrm{c}$ \\
LSD $_{0.05}$ & 8.1 & 8.7 \\
\hline
\end{tabular}

${ }^{w}$ Field experiments were conducted in the rainy season (July-October 2001) and winter season (November 2001-February 2002). The experimental design was a randomized complete block of six treatments with three replications, each with six plants.

${ }^{x}$ PGPR strain identifications: Strain IN937a = Bacillus amyloliquefaciens; Strains IN937b, SE34, SE49, T4, and INR7 = B. pumilus.

${ }^{y}$ Mean disease severity. Disease was rated 14 days after challenge by determining percentage of fruit area covered with lesions.

${ }^{z}$ Numbers with different letters show significant differences at $P=0.05$ according to least significant difference (LSD) test.

Table 6. Effect of plant growth-promoting rhizobacteria (PGPR) on yield of long cayenne pepper in field trialsw

\begin{tabular}{lcc}
\hline Treatment $^{\mathbf{x}}$ & $\begin{array}{c}\text { Mean } \\
\text { (kg/plot) } \\
\text { (rainy) }\end{array}$ & $\begin{array}{c}\text { Mean } \\
\text { (kg/plot) }^{\mathbf{y}} \\
\text { (winter) }^{\text {(wonn }}\end{array}$ \\
\hline Control & $1.8 \mathrm{~d}^{\mathrm{z}}$ & $1.4 \mathrm{c}$ \\
IN937a alone & $1.9 \mathrm{~cd}$ & $1.7 \mathrm{bc}$ \\
IN937a+IN937b & $2.0 \mathrm{bc}$ & $1.8 \mathrm{abc}$ \\
IN937b+SE34 & $2.1 \mathrm{~b}$ & $1.9 \mathrm{abc}$ \\
IN937b+SE49 & $2.4 \mathrm{a}$ & $2.0 \mathrm{ab}$ \\
T4+INR7 & $2.5 \mathrm{a}$ & $2.3 \mathrm{a}$ \\
LSD $_{0.05}$ & 0.1 & 0.5 \\
\hline
\end{tabular}

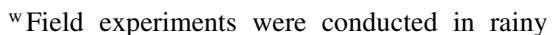
(July-October 2001) and winter seasons (November 2001-February 2002). The experimental design was a randomized complete block of six treatments with three replications, six plants each.

$\times$ PGPR strain identifications: Strain IN937a $=$ Bacillus amyloliquefaciens; Strains IN937b, SE34, SE49, T4, and INR7 = B. pumilus.

y Mean total fruit weight from six plants per plot from one harvest (14 days after challenge).

${ }^{\mathrm{z}}$ Numbers with different letters show significant differences at $P=0.05$ according to least significant difference (LSD) test. 
PGPR. These defenses include lignification, peroxidase, and superoxide dismutase (SOD) production in cucumber (16), production of peroxidase (1) and phenolic compounds in cell wall appositions in pea (4), phytoalexin production in carnation (31), and lignification in bean (2). van Wees et al. (32) suggested that a single bacterium may induce systemic resistance through more than a single mechanism.

Pierson and Weller (25) reported that some combinations of fluorescent pseudomonad strains increased wheat yield compared with the same strains used individually. They also found that the best combinations did not always produce the same results in different crops. We found that strain mixture IN937a + IN937b generally improved yield of all plants compared with that of plants treated with individual strain IN937a, suggesting that the mixture could be useful on tomato, long cayenne pepper, and cucumber. Part of the reason for the difference in our results and those of Pierson and Weller may be that we used spore-forming strains of Bacillus spp. and different crop species and conducted our work under tropical environmental conditions.

Many mechanisms have been related to plant growth elicited by PGPR, including fixing atmospheric nitrogen and supplying it to plants, chelating iron from the soil and providing it to the plant cell, synthesizing several different phytohormones to enhance various stages of plant growth, solubilizing phosphorus for plant growth, and synthesizing some uncharacterized, lowmolecular-mass compounds or enzymes that modulate plant growth and development $(5,8,17-19,24)$. All PGPR strains in our study were Bacillus spp., which have been reported to produce a monocatecholate siderophore, 2,3-dihydroxybenzol glycine (14). Further research is needed to discern the mechanisms elicited by the PGPR mixtures that promoted plant growth in our study.

Our results indicate the potential of using PGPR strain mixtures for broad-spectrum protection against multiple diseases in Thai vegetable inter-cropping systems. Compared with the current use of pesticides to achieve disease protection, the use of PGPR mixtures presents fewer environmental risks. Another benefit of using PGPR strain mixtures is the enhancement of plant growth and yield. However, studies in different geographical areas in Thailand and of modified methods of PGPR application are needed to assess the consistency and effectiveness of PGPR strains as a component of an integrated program for management of vegetable diseases.

\section{ACKNOWLEDGMENTS}

This work was funded from the Thailand Research Fund (TRF) (grant no. PDF4380048). We thank Natthapong Hoysung and Chusak Raksanau for technical assistance in harvesting and processing samples.

\section{LITERATURE CITED}

1. Albert, F., and Anderson, A. J. 1987. The effect of Pseudomonas putida colonization on root surface peroxidase. Plant Physiol. 85:537-541.

2. Anderson, A. J., and Guerra, D. 1985. Responses of bean to root colonization with Pseudomonas putida in a hydroponic system. Phytopathology 75:992.

3. AVRDC, 1989. Tomato and pepper production in the tropics. Pages 561-576 in: Proc. Int. Sympos. Integrated Manag. Practices, 2126 March 1989. B. T. McLean, S. K. Green, and T. D. Griggs, eds. Asian Vegetable Research and Development Center (AVRDC), Shanhua, Tainan, Taiwan.

4. Benhamou, N., Kloepper, J. W., QuadtHallman, A., and Tuzun, S. 1996. Induction of defense-related ultrastructural modifications in pea root tissues inoculated with endophytic bacteria. Plant Physiol. 112:919-929.

5. Brown, M. E. 1974. Seed and root bacterization. Annu. Rev. Phytopathol. 12:181-197.

6. Chamswarng, C. 1991. Biological control of Sclerotium stem rot of tomato in Thailand. J. Plant Prot. Trop. 8:1-7.

7. Chamswarng, C. 1995. Application of Trichoderma biofungicide for the recovery of durian decline caused by Phytophthora root rot. Pages 41-47 in: Proc. Semi-Annu. Project Workshop 1995. Thai-Germany IPM Technology Development in Fruit Crop. 12-24 June 1995. Bangkok, Thailand.

8. Davison, J. 1988. Plant beneficial bacteria. Bio/Technology 6:282-286.

9. Department of Agriculture. 1993. Sustainable agriculture: The future of Thai farmers. Pages 118-129 in: Annual Technical Bulletin for 1993. Ministry of Agriculture and Cooperatives, Thailand.

10. Dixon, G. R. 1981. Vegetable Crop Diseases. MacMillan Publishing, London.

11. Hartman, G. L., and Datnoff, L. E. 1997. Vegetable crops. Pages 151-170 in: Soilborne Diseases of Tropical Crops. R. J. Hillocks and J. M. Waller, eds. CAB International, Wallingford, UK.

12. Intanoo, W., and Chamswarng, C. 1996. Increased efficacy for biocontrol of tomato stem rot and barley seedling blight by benomyl resistant mutant of Trichoderma harzianum. Pages 507-514 in: Proc. 3rd AsiaPacific Conf. Agricultural Biotechnology: Issues and Choices. 10-15 November 1996.

13. Intanoo, W., Chamswarng, C., and Graiyoth, S. 1998. Comparison of Gliocladium spp. isolates for the control of Pythium damping-off of Chinese kale (Brassica oleracea). Page 48 in: Abstracts of Presentations at the International Conference on Peri-Urban Vegetable Production in the Asia-Pacific Region for the 21st Century. 29 September - 1 October 1998. Bangkok, Thailand.

14. Ito, T., and Neilnad, J. B. 1958. Products of "low-iron fermentation" with Bacillus subtilis: Isolation, characterization and synthesis of 2,3-dihydroxybenzoylglycine. J. Am. Chem. Soc. 80:4645-4647.

15. Jetiyanon, K., and Kloepper, J. W. 2002. Mixtures of Plant Growth Promoting Rhizobacteria for Induction of Systemic Resistance Against Multiple Plant Diseases. Biol. Control 24:285-291.

16. Jetiyanon, K., Tuzun, S., and Kloepper, J. W. 1997. Lignification, peroxidase and superoxide dismutases as early plant defense reactions associated with PGPR-mediated induced systemic resistance. Pages 265-268 in: Plant GrowthPromoting Rhizobacteria-Present Status and Future Prospects. A. Ogoshi, K. Kobayashi, Y. Homma, F. Kodama, N. Kondo, and S. Akino, eds. Nakanishi Printing, Sapporo, Japan.

17. Kloepper, J. W., Lifshitz, R., and Zablotowicz, R. M. 1989. Free-living bacterial inocula for enhancing crop productivity. Trends Biotechnol. 7:39-43.

18. Kloepper, J. W., Scher, F. M., Laliberte, M., and Tipping, B. 1986. Emergence-promoting rhizobacteria: Description and implications for agriculture. Pages 155-164 in: Iron, Siderophores, and Plant Disease. T. R. Swinburne, ed. Plenum Publishing Corp., New York.

19. Lambert, B., and Joos, H. 1989. Fundamental aspects of rhizobacterial plant growth promotion research. Trends Biotechnol. 7:215-219.

20. Liu, L., Kloepper, J. W., and Tuzun, S. 1995 Induction of systemic resistance in cucumber against Fusarium wilt by plant growth-promoting rhizobacteria. Phytopathology 85:695-698.

21. Liu, L., Kloepper, J. W., and Tuzun, S. 1995. Induction of systemic resistance in cucumber against angular leaf spot by plant growthpromoting rhizobacteria. Phytopathology 85:843-847.

22. Murphy, J. F., Zehnder, G. W., Schuster, D. J., Sikora, E. J., Polston, J. E., and Kloepper, J. W. 2000. Plant growth-promoting rhizobacterial mediated protection in tomato against Tomato mottle virus. Plant Dis. 84:779-784.

23. Office of Agricultural Economics. 1999. Agricultural Statistics of Thailand Crop Year 1997/1998. Ministry of Agriculture and Cooperatives, Thailand.

24. Pattern, C. L., and Glick, B. R. 1996. Bacterial biosynthesis of indole-3-acetic acid. Can. J. Microbiol. 42:207-220.

25. Pierson, E. A., and Weller, D. M. 1994. Use of mixtures of fluorescent pseudomonads to suppress take-all and improve the growth of wheat. Phytopathology 84:940-947.

26. Raupach, G. S., and Kloepper, J. W. 1997. Integrated pest management of multiple cucumber pathogens through PGPR-mediated induced systemic resistance. Pages 281-282 in: Plant Growth-Promoting RhizobacteriaPresent Status and Future Prospects. Proc. Int Work-shop Plant Growth-Promoting Rhizobacteria, 4th. A. Ogoshi, K. Kobayashi, Y. Homma, F. Kodama, N. Kondo, and S. Akino, eds. Nakanishi Printing, Sapporo, Japan.

27. Raupach, G. S., and Kloepper, J. W. 2000. Biocontrol of cucumber diseases in the field by plant growth-promoting rhizobacteria with and without methyl bromide fumigation. Plant Dis. 84:1073-1075.

28. Raupach, G. S., Liu, L., Murphy, J. F., Tuzun, S., and Kloepper, J. W. 1996. Induced systemic resistance in cucumber and tomato against cucumber mosaic cucumovirus using plant growth-promoting rhizobacteria (PGPR). Plant Dis. 80:891-894.

29. Soytong, K. 2000. Application of a new broad spectrum biological fungicide for environmental protection. Pages 8-26 in: Advanced Study on Plant Pest Biological Control. Yan Qian, ed. International Symposium on Plant Pest Biological Control. Harbin Institute of Technology, Harbin, P.R. China. Heilongjiang Science and Technology Press.

30. Tindal, H. D. 1983. Vegetable in the Tropics. McMillan Publishing, London.

31. van Peer, R., Niemann, G. J., and Schippers, B. 1991. Induced resistance and phytoalexin accumulation in biological control of Fusarium wilt of carnation by Pseudomonas sp. strain WCS417r. Phytopathology 81:728.

32. van Wees, S. C. M., Pieterse, C. M. J., Trijssenaar, A., van Westende, Y. A. M., Hartog, F., and van Loon, L. C. 1997. Differential induction of systemic resistance in Arabidopsis by biocontrol bacteria. Mol. Plant-Microbe Interact. 6:716-724

33. Wei, G., Kloepper, J. W., and Tuzun, S. 1996. Induced systemic resistance to cucumber diseases and increased plant growth by plant growth-promoting rhizobacteria under field conditions. Phytopathology 86:221-224. 